\title{
Effectiveness of the Value Added Tax Exemption Policy on Gross Domestic Product in Selected ASEAN Countries Towards a Conducive Business Environment Model
}

\author{
Atty. Prackie Jay T. Acaylar, CPA, JD, MPA, PhD-BM, FRILL ${ }^{1}$ \\ ${ }^{1}$ Technological Institute of the Philippines, Manila
}

\begin{abstract}
Excessive exemption is detrimental to the effectiveness of the whole Value Added Tax system. This research is primarily focused on VAT exemption affecting the business industry as it influences the Gross Domestic Product of the three (3) selected ASEAN countries, namely, the Philippines, Indonesia, and Singapore. The result of the study showed a negative relationship between VAT exemption policy and GDP growth rate among the selected ASEAN economies. Although the VAT collections among the selected ASEAN countries are significantly increasing with the course of time, the results showed that as the number of VAT exemptions increases by one unit, the degree of growth of the GDP is expected to decrease at a rate of 0.900 units. Thus, a conducive business environment may be achieved by decreasing the number of VAT exemptions and, accordingly, increasing the GDP growth rate.
\end{abstract}

Keywords: Value Added Tax, Gross Domestic Product, VAT Exemption Policy, ASEAN economies, GDP Growth Rate

This is an open access article under the CC-BY-NC license

\section{INTRODUCTION}

Taxation is important to society and to the country as a whole. The tax collected is utilized to finance programs of the Government relating to the general welfare of the people; it can be used to improve employee benefits, provide pensions, and other social services and benefits for its citizens. Taxation is fundamental and imperative to the economy of the country. It is used to help businesses and push the economy in cases of pandemic and financial recession. Taxation, therefore, plays a better prospect for the country as it buildups its economic welfare.

There are several kinds of taxes imposed by the Bureau of Internal Revenue (BIR), the tax administrator of the country. This study is focused on a particular kind of taxation, which is the Value Added Tax (VAT), highlighting the crucial roles of VAT exemptions.

VAT is a consumption tax imposed on the sale, barter, exchange, or lease of goods or properties and services. It is an indirect tax, which may be transferred on to the consumer, transferee, or lessee of goods, properties, or services. It is also a type of indirect tax gathered at different phases of the productiondistribution series. If correctly planned and executed, the VAT is efficiently collected on the genuine enhanced value produced at that phase; as such, the VAT may be treated as a distinct retail sales tax applied in a distinctive style.

The VAT affects all persons who sell, barter, exchange, or lease goods or properties or renders services in the pursuit of a trade or business, provided that the total sales or receipts surpass the maximum 
limit. The term "in the pursuit of trade or business" refers to the ordinary and habitual conduct of the business activity, including dealings incidental thereto.

One of the roles of VAT in the country is its influence on fiscal development. In developing countries like the Philippines, VAT contributes to the Gross Domestic Product (GDP) of the economy, leading to fiscal development.

GDP is one of the most commonly employed instruments of the country's economy. It is the entire worth of products manufactured within a country's boundaries in a particular period. It is one of the main gauges utilized to evaluate the wellbeing of a particular economy. This study primarily focused on VAT exemption affecting the business industry as it influences the GDP of the three (3) selected countries in the Association of Southeast Asian Nations (ASEAN), namely, the Philippines, Indonesia, and Singapore.

It should be emphasized that excessive VAT exemptions are injurious to the effectiveness of the entire VAT policy, augment unintentional misrepresentations, and inflict bigger inconvenience on the tax management. Multiple exemptions inescapably diminish the VAT output and would shrink the resources required to aid the underprivileged, push Governments to formulate an impromptu amendment in the tax system and generate ambiguity in the commercial milieu. This study focused on the many loopholes of the VAT exemptions. Evidently, the Philippine VAT system has too many exemptions and loopholes. Thus, fewer exemptions and loopholes will result in more collections for the Government.

The stumpy percentage of VAT collection to GDP is caused by profuse exemptions under the Philippine VAT system. Prior to RA 10963 or the Tax Reform for Acceleration and Inclusion (TRAIN) Law, it is noted that there were 59 VAT exemptions in the Philippine Tax Code; Indonesia has 37 exemptions, Thailand 37, Vietnam 25, and Singapore 7. On top of the 59 VAT exemptions, under special laws, there are more than 80 entities/individuals who are afforded VAT exemptions in the Philippines. Some special laws provide for explicit VAT exemption, while others provide for exemption from all taxes, including VAT, or a certain tax rate in lieu of all taxes, including VAT (Jurado, 2017). Under the TRAIN Law, the Philippines reduced the exemptions from 139 to 53.

This study showed how and why, in the face of innumerable modification endeavors for the past decades, the VAT policy of the Philippines persists to deteriorate from lingering flaws. Based on the study conducted by the World Bank (2015), it was estimated that the median VAT variance from 2006 to 2013 denoted nearly $63 \%$ of possible VAT income. Of this, $28 \%$ was a consequence of permissible exclusions and distinctive treatment, while $35 \%$ may be concomitant with nonfulfillment. The same research observed that some exclusions under the existing VAT policy have a tendency to generate fiscal misrepresentations (Manasan, 2017).

The enactment of the TRAIN Law on January 1, 2018, has reduced the number of VAT exemptions; nevertheless, some VAT exemptions under the new TRAIN Law tend to create economic distortions and redundancy. This is because the VAT exemption under the TRAIN law did not totally remove those unreasonable exemptions. Thus, the base of VAT has to turn out to be too restricted because of copious exemptions (Manasan, 2017). Consequently, the tax policy has and will persistently fall short of reaching the recognized income collection and forced Government's competence to fund comprehensive development.

Based on the study conducted by the National Tax Research Center (NTRC), six (6) countries of the ten (10) members of the ASEAN are levying the VAT, viz., Philippines, Cambodia, Lao People's Democratic Republic (PDR), Thailand, Vietnam, and Indonesia. The three (3) countries, namely Singapore, Myanmar, and Malaysia levy the VAT-like consumption tax, which is the Goods and Services Tax (GST). Brunei, on the other hand, does not impose VAT or its counterpart consumption tax (Jurado, 2017). 
The research effected by the Organisation for Economic Co-operation and Development (OECD) presents that VAT was at the beginning established to simplify the commercial transaction, predominantly among the European Union. It was developed to apply at the border on imports and refunded at the border on exports, avoiding taxes from increasing whenever goods moved through a country. VAT does this by putting on gradual taxes at every phase of production, with invoice marks itemizing how much tax was entrenched in the selling price.

Another study conducted by the World Bank (2005) on tax policy in developing countries reveals that VAT is more intricate to manage than other forms of consumption tax, and the intricacy normally points to high collection costs. However, the taxes superseded by the VAT in some countries, like the Philippines, are commonly complicated in their outline and pierced with constricted tax base, compound rates, and copious exclusions. This study evaluated the VAT exemption with the end view of eliminating double or redundant benefits that the laws or statutes may have accorded to selected unqualified corporations. The same study reveals that a non-exemption VAT would prevent the spilling issues and thus would not breed misrepresentation in production. In addition, a comprehensive-based VAT reduces burden loss intrinsic in any form of consumption tax. These enviable attributes of the VAT are, however, foregone if the tax is pierced with several exclusions. Thus, too much exemption in VAT leans to wear down the VAT base, diminish the income collection, on the one hand, split the VAT sequence and in so doing stimulate spilling issue on the other.

This study used the Harrod-Domar Theory of Economic Growth to establish the conditions of wealth to attain a specified rate of fiscal growth (Harrod, 1939; Domar, 1946). Harrod-Domar Theory is used since it is useful in designing models to raise resources (Chetty and Pradhan, 2015) and justifying how economies would need to grow (or would be left to stagnate) over time. Moreover, since this study determined the significant relationship between VAT exemption and growth rate in ASEAN Region and proposed a model for the conducive business environment, it used the growth rate theory developed by Walt Whitman Rostow. Rostow's Growth Rate Theory is a structuralist paradigm of fiscal growth. It is a function of the liberal school of economics placing importance on the effectiveness of contemporary thoughts of free trade. It is a theory of growth that is primarily concerned with the national economy (Parr, 2001), and it is one of the foremost historical paradigms of fiscal growth (Henegedara, 2016). Rostow Growth Theory was accepted as a Governmental concept as well as an illustrative fiscal study of progress and development. (Thirlwall, 2002)

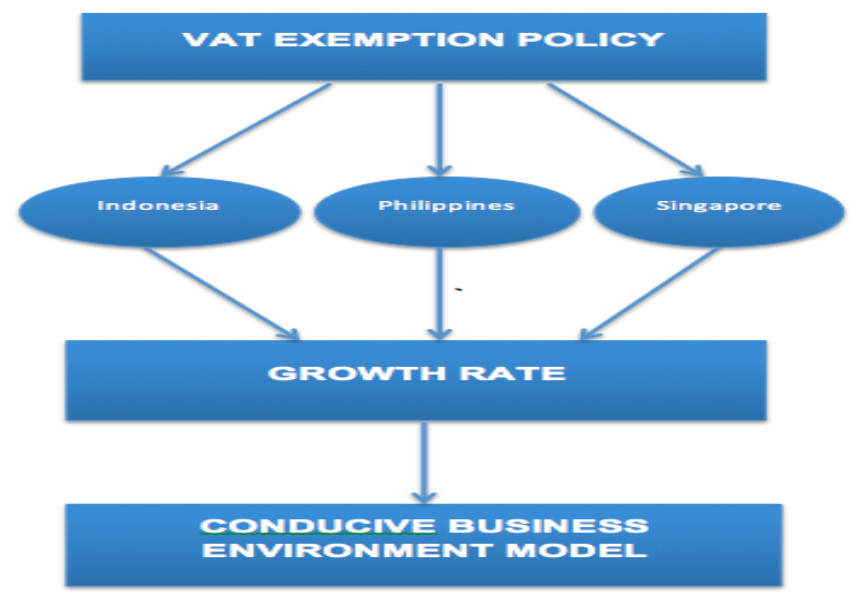

Figure 1. Research Framework 
As shown in Figure 1, the input is the secondary data on VAT collection of the selected ASEAN countries and the percentage to GDP for the years 2000-2015. The process is the identification of a significant relationship between VAT exemption and growth rate in the ASEAN Region. The output is the proposed conducive business environment model.

\section{RESEARCH METHOD}

Documents were employed since this study deals with documents. The analysis and interpretation of data were made in light of the general vision of the VAT exemption policy using the directed approach specific to this method. The secondary data used in this study are total VAT collection and its percentage to GDP and the list of VAT exemptions from the selected ASEAN countries. VAT collection, as a percentage of GDP, was used to investigate trends in VAT collection in ASEAN Region. To confine the focal point of this research, statistics throughout the period of 2000-2015 are used to analyze the trend of VAT collection as a percentage to GDP on three (3) selected ASEAN countries. Accordingly, analysis on VAT exemption policy will be limited only to the three (3) selected ASEAN countries. In order to determine the extent of the effect of VAT exemption on the growth rate, as well as their significant relationship, the list of VAT exemptions from the selected ASEAN countries was analyzed. This study used the Least Square Method, Regression, Simple Regression, Multiple Regression, and analysis of variance (ANOVA) as statistical tools in analyzing the secondary data.

\section{Data Gathering Procedures}

The main foundations of secondary data for this study are the collection from the libraries of BIR, NTRC, International Monetary Fund (IMF), Department of Finance (DOF), and Bangko Sentral ng Pilipinas (BSP); websites of Indonesian, Singapore, and Philippine Government departments/agencies; and other websites with prevailing quantitative figures and statistics linked to VAT system of the ASEAN countries being deliberated. The VAT rates statistics gathered from Klynveld Peat Marwick Goerdeler's (KPMG) records were ascertained by comparing it with taxation data from big local and international auditing firms such as Price Waterhouse Coopers (PWC), Deloitte Touche Tohmatsu, Binder Dicker Otte (BDO), Isla Lipana \& Co., and Sycip Gorres \& Velayo (SVG). Statistics on tax income were obtained from precise source such as the Ministry of Finance or the Tax Department of the selected ASEAN countries.

\section{FINDINGS AND DISCUSSION}

Tax-to-GDP shares are affected by an array of local and international components. Aizenman et al. (2015) observed that in Asia, Government efficiency and organization value are definitely associated with the level of relationship between tax and GDP. The geographic position is also significant: closed-in countries are inept at levying taxes on goods and services moving in the country than island countries (UNESCAP, 2014). In addition, international issues, comprising the tax system of other countries, can influence tax-to-GDP relations. Several studies have been conducted showing that lowVAT collection may be attributable to numerous VAT exemptions. Thus, for a VAT system to be effective, the Government must lessen the number of exemptions to a certain degree possible. 


\section{Trend of VAT Collection in Selected ASEAN Countries Within the Last Sixteen (16) Years.}

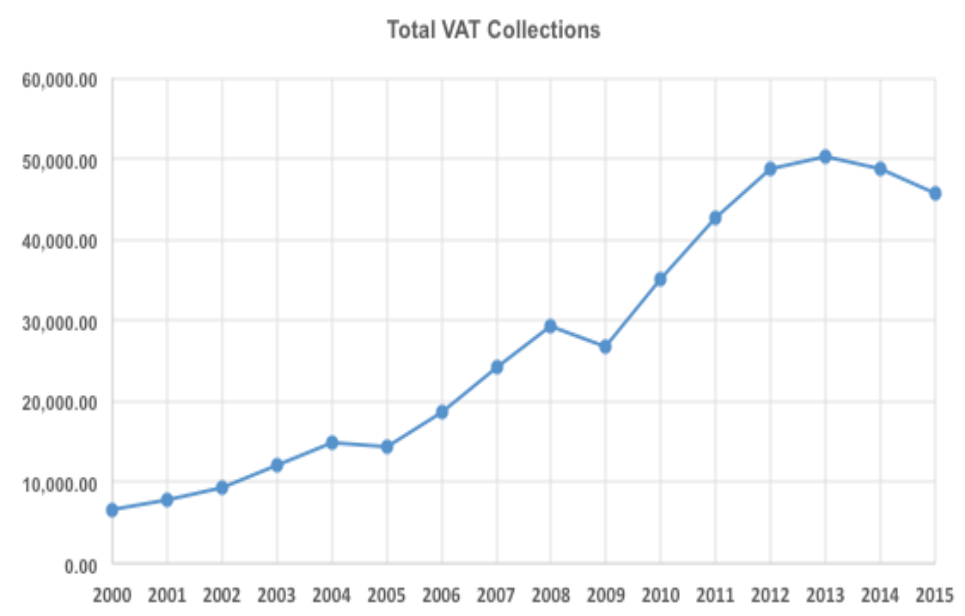

Figure 2. Total VAT Collections Among Selected ASEAN Economies 2000-2015 (Values are in Million US Dollars)

The figure above shows the historical trend of VAT collections among ASEAN economies such as the Philippines, Indonesia, and Singapore based on the secondary data gathered. Except for a few years $(2005,2009,2014$, and 2015), there has been a consistent increase in the number of VAT collections in the last 16 years.

Results of the linear regression provide further analyses on the trend of VAT collections in the last 16 years.

Table 1 - Linear Trend Model Results for VAT Collections Among Selected ASEAN Economies 2000-2015

\begin{tabular}{|l|c|c|c|c|}
\hline \multirow{3}{*}{ Predictors } & \multicolumn{4}{|c|}{ Dependent Variable: VAT Collections } \\
\cline { 2 - 4 } & $\begin{array}{c}\text { Beta } \\
\text { Coefficients }\end{array}$ & $\begin{array}{c}\text { t-statistic } \\
\text { (p-value) }\end{array}$ & $\begin{array}{c}\text { F-ratio } \\
\text { (p-value) }\end{array}$ & R-squared \\
\hline Constant & -557.420 & $\begin{array}{c}-0.274 \\
(0.788)\end{array}$ & 241.871 & \multirow{2}{*}{0.972} \\
\hline Time Variable & $3,270.713$ & $\begin{array}{c}15.552 \\
(0.000)\end{array}$ & $(0.000)$ & \\
\hline
\end{tabular}

The table above summarizes the trend results of the VAT collections for the selected ASEAN economies. The R-squared, which serves as the coefficient of determination, provides a measure of how much of the VAT collections are accounted for from the element of time. The value of the R-squared relates that $97.2 \%$ of the variations in the VAT collections are explained by the element of time.

The F-ratio provides a measure of the model's overall significance. The computed F-ratio (241.871) has a p-value of 0.000 , less than the level of significance of 0.05 . This, in effect, relates that the formulated linear trend model is significant. The t-statistics provide a measure of the beta coefficients' individual 
Journal of Governance Risk Management Compliance and Sustainability (JGRCS), Vol. 1 (1), 01-17 Effectiveness of the Value Added Tax Exemption Policy on Gross Domestic Product in Selected ASEAN Countries Towards a Conducive Business Environment Model Atty. Prackie Jay T. Acaylar, CPA, JD, MPA, PhD-BM, FRILL

significance. Between the 2 predictors, the Constant generated a t-statistic, with p-value (0.788) greater than the level of significance of 0.05 . This, in effect, relates that the constant is not a significant predictor in the linear trend model.

However, results are different for the time variable. The time variable generated a t-statistic with p-value (0.000), less than the level of significance of 0.05 . This, in effect, relates that time is a significant predictor of the number of VAT collections in the last 16 years.

The regression (beta) coefficient of time particularly relates that, on average, the amount of VAT collections increases at a rate of USD 3,270.713 million every year. When the regression result is summarized to an equation, the resulting linear trend model is shown below.

$$
\text { VAT Collections }=\quad-557.420+3,270.713 \text { time }
$$

For comparison purposes, figures for the 3 selected ASEAN countries are heretofore presented on a per-country basis.

\section{Trend of VAT Collections: Per Country}

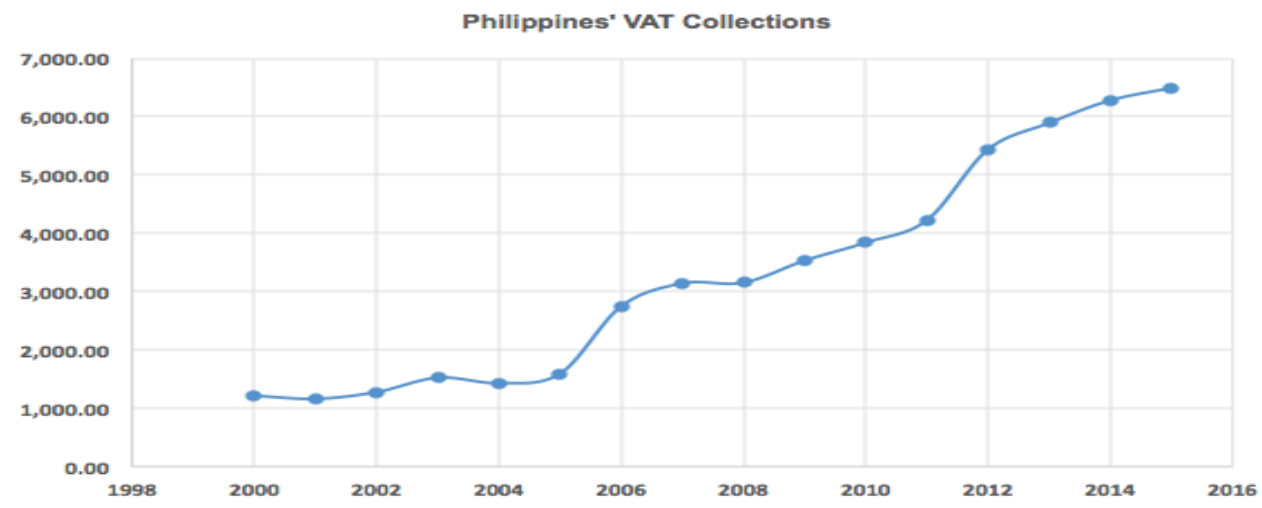

Figure 3. Total VAT Collections of the Philippines : 2000-2015 (Values are in Million US Dollars)

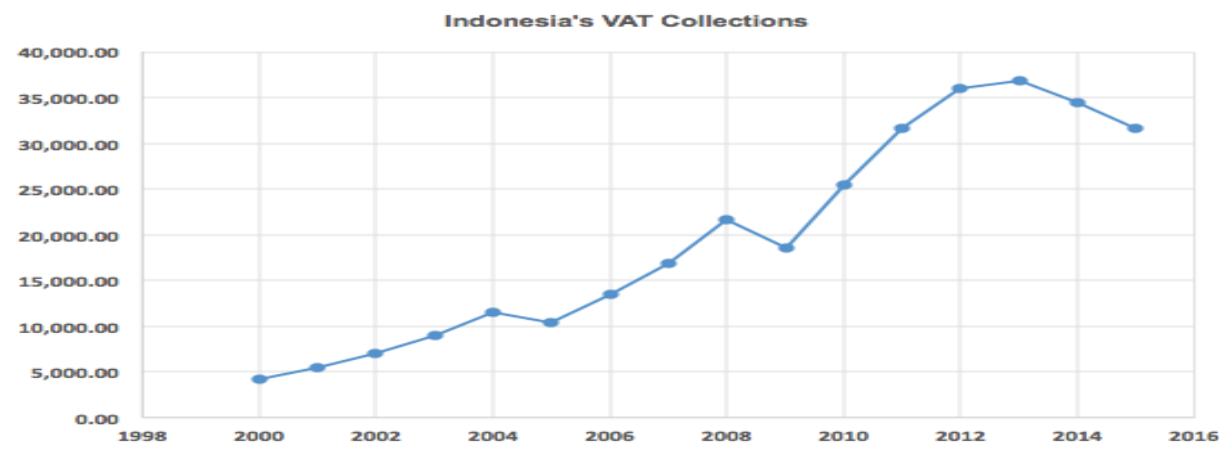

Figure 4 - Total VAT Collections of Indonesia : 2000-2015 (Values are in Million US Dollars) 


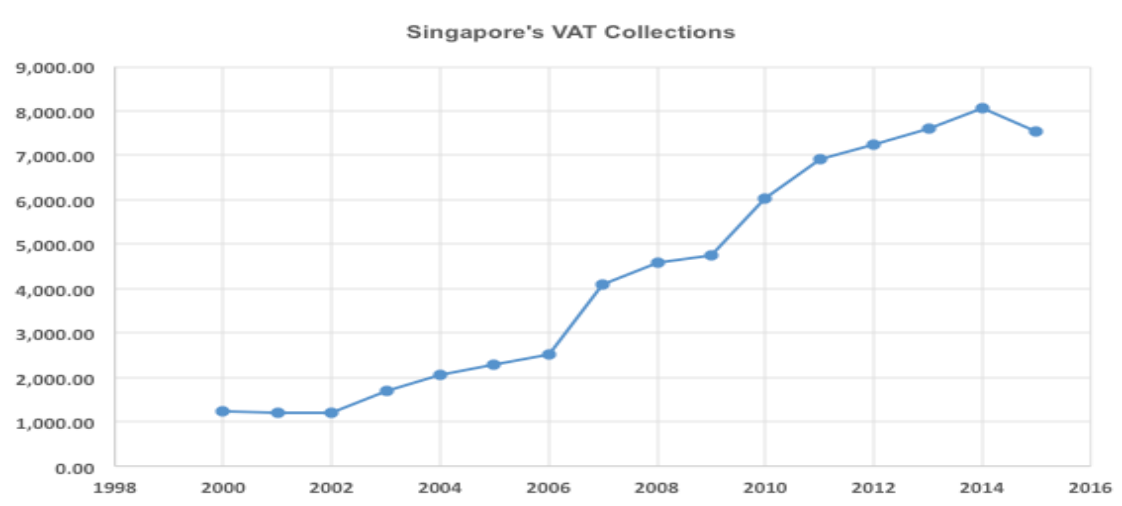

Figure 5 - Total VAT Collections of Singapore : 2000-2015 (Values are in Million US Dollars)

Consistent with the overall trend, the Philippines, Indonesia and Singapore recorded continuously increasing trend in VAT collections. However, it should be emphasized that there were a few noted years when collections posted a decline.

\section{Philippines : Trend of VAT Collections}

In the case of the Philippines, collections posted a decline in 2004 and 2008. The decline of VAT collection may be caused by several factors like vulnerable tax management, failure to link the excises to price increases, and the vain attempt to merge trade liberalization with counterbalancing income measures, as well as the Government's decisiveness in 2002 to restraint buildups in electricity tariffs and VAT exemption.

In 2004, Philippines long advocated increasing the VAT rate from $10 \%$ to $12 \%$, which was relatively tolerant given the exemption of small companies and unrefined food (IMF, 2005). Thus, when RA 9337 was implemented in 2005, which raised the VAT rate from $10 \%$ to $12 \%$, total VAT collections increased from PhP156.7 billion in 2005 to PhP259.8 billion in 2006.

Another reason for the increase of VAT collection in 2006 is the expanded coverage of the VAT, courtesy of RA 9337, by including the energy and power sectors, nonfood agricultural, marine and forest products, importation of coal and natural gas, services of doctors and lawyers, common domestic carriers by air and sea, among others (Obias, Jr., 2010). Hence, it could be said that the increase in 2006 VAT collection is partly caused by the removal of the VAT exemption of the aforesaid products, groups, and individuals.

Moreover, it was during 2004 that IMF (2005) proposed various initiatives to eradicate motivations from a substantial amount of incongruent economic laws, comprising those given to cooperatives (bearing a possibly considerable quantity of income) and eliminating unusual VAT exemptions such as for petroleum products (generating $0.2 \%$ to $0.3 \%$ of GDP). The IMF saw that the concern in the decline of VAT collection might be minimized by the repeal of several nonstandard special VAT exclusions, such as the VAT exclusion of petroleum, which also embody a valuable prospective basis of income.

The decline in 2008 VAT collection was due to the lifting of the $70 \%$ cap on the quantity of input taxes that may be claimed against output tax pursuant to RA 9361, utilization of available excess input tax that accumulated in 2006, and claim of higher input taxes brought about by high prices of raw materials and utilities and additional purchases of capital goods (Obias, Jr., 2010). The negative growth in VAT was due, among others, to (a) amplified input tax asserted by importers and taxpayers with more than PhP1 
million capital expenditures in 2007, amortized in 2008; (b) slowdown in cement industry, (c) decrease in overall hotel occupancy; and (d) lower growth in the construction industry (BIR, 2008).

\section{Indonesia : Trend of VAT Collections}

Indonesia also recorded a continuous increase in the number of VAT collections in the last sixteen (16) years. However, there were also years when it recorded a slight decline in collections. The said years include 2005, 2009, and the recent years of 2014 and 2015.

The decline in VAT collection in the said years was caused by several factors. For instance, 2004 was an election year in Indonesia that led to the election of President Yudhoyono in October 2004 (IMF, 2005). The skepticism of the business and investors caused by-election had contributed to the decline in VAT collection. Moreover, December 26, 2004 earthquake and tsunamis-and the earthquake that struck in March 2005-wreaked a massive toll on Indonesia in terms of loss of life and destruction to infrastructure and homes in the province of Nanggroe Aceh Darussalam. This catastrophic event contributed to the decline in VAT collection. It was also during this taxable year that the tax policy stayed behind, tarnished by depleted non-oil income collection instigated by significant VAT exemptions, stumpy excise tax levels, and weak implementation, and prevalent dishonesty. The decline can also be attributed to VAT exemptions granted to capital goods, the mining sector, and hotel and restaurant services. Lastly, one dominant reason caused for the decline is the large informal sector of the Indonesian economy, making the tax base of registered taxpayers in Indonesia remains one of the lowest in the world (Indonesia Focus, 2018).

The decline in VAT collection in 2009 may be caused by various factors affecting investors'

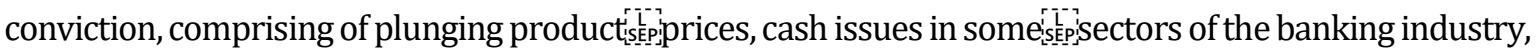
nonpayment on 1994 to 2009 statistics, World Bank research categorized Indonesia as a country with little tax attempt and tax collection. This indicates that income is accumulated less than the utmost capability, and World Bank recommended that importance should be placed on income improvement by way of system and management restructurings.

In 2014, the decline in VAT collection was partially brought about by too much exemption. Hence, Indonesian authorities were urged to pursue tax reforms focusing on initially widening the base, restructuring exemptions (notably the VAT), and enhancing risk-based tax administration. This proposal resulted in harmonizing improvements, comprising of leveling corporate tax rates, reinforcing the property tax regime, and enhancing the VAT rate and select excises. Another factor resulting in a decrease in VAT collection in 2014 was the mid-year election. Further, the research conducted by Deloitte (2014) observed that indiscriminate and partial tax valuations in Indonesia were still widespread, further wearing down the taxpayers' faith in the capability of the tax administration to decide disputes in a reasonable way. This insight of partiality might operate as a basic obstacle to developing broader confidence between the citizens and Government. Moreover, there are many exemptions on products and services. These include mining and drilling products, food and drinks distributed in hotels and restaurants, various services, including healthcare, social welfare, postal delivery, financial services, religion, education, culture, and entertainment (IBFD, 2017). IMF (2017) estimated that the VAT revenue loss due to exemptions on the final consumption of goods and services in Indonesia amounted to $0.8 \%$ of GDP. Many exemptions in Indonesia relate to intermediate consumption leading to a cascading effect. IMF (2017) estimated that this amounted to around $0.9 \%$ of GDP. 
The decline in 2015 VAT collection may be caused by the abrupt decrease in international oil prices, occurrences of capital outflows, and blustery worldwide financial markets. Government revenues, including VAT, decreased by 1.7 percentage points to $13 \%$ of GDP, mainly due to the quick reduction in oil prices. On revenue mobilization, the authorities viewed that Indonesia's low tax-to-GDP ratio stems mainly from problems in tax administration and compliance, including arising from a complex VAT refund system and the strict bank secrecy rule that prevents access to taxpayers' financial data. In their view, Indonesia will need to enhance the menu of tax incentives in line with those offered by other ASEAN countries. Further, compliance level was also little and minimal, an issue already observed by the World Bank in the 1990s.

Nearly half of the taxpayers who were compelled to file tax returns did so. It should be emphasized that the self-assessment policy as used in Indonesia depends on voluntary obedience. Supposedly, voluntary obedience is expected to occur if the revenue authority is able to establish a service-client approach causing an improved faith in the authority. In 2015, an expected 44 million people should be paying taxes. However, only 27 million were registered, and less than $40 \%$ paid the full amount of tax. Revenues from each tax category as a percentage of GDP decreased in Indonesia, with corporate income tax and VAT revenues most affected over this period (Basri and Rahardja, 2011).

\section{Singapore: Trend of VAT Collections}

Compared with the Philippines and Indonesia, Singapore's amount of VAT collections posted more fluctuations. Though in general, its level of collections still posted an increasing trend. The taxable year 2015 posted a decline in VAT collection. The decline in VAT collection is caused by several factors relating to economic recession and expansion of VAT exemption.

In 2015, as an extremely accessible and free economy, Singapore was subjected to outside risks, including a prolonged sluggish development in progressive and developing economies and unpredictability in worldwide monetary markets. Domestic vulnerabilities amplified the impact of external shocks. Consumption growth slackened significantly, and aggregate fixed investment influenced undesirably to development, apprehended by the indecisive financial viewpoint and its influence on investor assurance. These events also affected the VAT collection.

For better understanding and comparison, figures are heretofore presented on a per-country basis. Thus, the succeeding tables, namely Tables 2,3 , and 4 , will present the individual results for the Philippines, Indonesia, and Singapore, respectively.

\section{Analysis : Per Country}

Table 2. Linear Trend Model Results for VAT Collections in the Philippines

\begin{tabular}{|l|c|c|c|c|}
\hline \multirow{2}{*}{ Predictors } & \multicolumn{4}{|c|}{ Dependent Variable: VAT Collections } \\
\cline { 2 - 3 } & $\begin{array}{c}\text { Beta } \\
\text { Coefficients }\end{array}$ & $\begin{array}{c}\text { t-statistic } \\
\text { (R-value) }\end{array}$ & $\begin{array}{c}\text { F-ratio } \\
\text { (R-value) }\end{array}$ & R-squared \\
\hline Constant & -0.315 & $\begin{array}{c}-0.001 \\
(0.999)\end{array}$ & $\begin{array}{c}241.114 \\
(0.000)\end{array}$ & 0.973 \\
\hline Time Variable & 389.437 & $\begin{array}{c}15.572 \\
(0.000)\end{array}$ & & \\
\hline
\end{tabular}

VAT Collections in the Philippines $=\quad-0.315+389.437$ time 
Journal of Governance Risk Management Compliance and Sustainability (JGRCS), Vol. 1 (1), 01-17

Effectiveness of the Value Added Tax Exemption Policy on Gross Domestic Product in Selected ASEAN Countries

Towards a Conducive Business Environment Model

Atty. Prackie Jay T. Acaylar, CPA, JD, MPA, PhD-BM, FRILL

Table 3. Linear Trend Model Results for VAT Collections in Indonesia

\begin{tabular}{|l|c|c|c|c|}
\hline \multirow{2}{*}{ Predictors } & \multicolumn{4}{|c|}{ Dependent Variable: VAT Collections } \\
\cline { 2 - 5 } & $\begin{array}{c}\text { Beta } \\
\text { Coefficients }\end{array}$ & $\begin{array}{c}\text { t-statistic } \\
(\mathrm{R} \text {-value })\end{array}$ & $\begin{array}{c}\text { F-ratio } \\
(\mathrm{p} \text {-value })\end{array}$ & R-squared \\
\hline Constant & -319 & $\begin{array}{c}-0.188 \\
(0.853)\end{array}$ & $\begin{array}{c}179.713 \\
(0.000)\end{array}$ & 0.928 \\
\hline Time Variable & $2,346.202$ & $\begin{array}{c}13.406 \\
(0.000)\end{array}$ & \\
\hline
\end{tabular}
VAT Collections in Indonesia $=\quad-319 \quad+2,346.202$ time

Table 4. Linear Trend Model Results for VAT Collections in Singapore

\begin{tabular}{|l|c|c|c|c|}
\hline \multirow{2}{*}{ Predictors } & \multicolumn{3}{|c|}{ Dependent Variable: VAT Collections } \\
\cline { 2 - 5 } & $\begin{array}{c}\text { Beta } \\
\text { Coefficients }\end{array}$ & $\begin{array}{c}\text { t-statistic } \\
(\mathrm{p} \text {-value) }\end{array}$ & $\begin{array}{c}\text { F-ratio } \\
\text { (p-value) }\end{array}$ & R-squared \\
\hline Constant & -238.105 & $\begin{array}{c}-0.794 \\
(0.441)\end{array}$ & \\
\hline Time Variable & 535.073 & $\begin{array}{c}17.249 \\
(0.000)\end{array}$ & 0.955 \\
\hline
\end{tabular}

VAT Collections in Singapore $=\quad-238.105 \quad+535.073$ time

Results of the linear regression showed that the Philippines, Indonesia and Singapore have an Rsquared value of $0.973,0.928$ and 0.955 , respectively. This relates that $97.3 \%, 92.8 \%$, and $95.5 \%$ of the variations in the number of VAT collections in the Philippines, Indonesia, and Singapore, respectively, are explained by the element of time.

Time is always an imperative subject for countless subjects like philosophy, literature, arts but also for science, being also a basis of deviations associated with the time characterization, time insight, or time dimension. Time is valuable, and never has this been accurate than when endeavoring to thread data components mutually to foresee the fascination and objective of the spectators that one pursued to motivate. It is one of the most significant capitals for individuals, companies, and for the national economy. It should be emphasized that the cost of time is very difficult to quantify. Due to the time attributes - rarity and irreversibility - time could be thought of as a vital political, environmental, socio-cultural, and economic value essential to attain a favorable and conducive business environment. The importance of the element of time underlines the aforesaid factors in achieving the proposed business environment model. It is distinct that time turns out to be a financial resource, and as a variable, it has to be enhanced, justified, and contained.

The element of time contributed greatly to the increase in the VAT collection during the period under study. The core of time incident is transformation; transformation in predilections, transformation in technology, transformation in population, transformation in the economy, society, environment, politics, taxes, etc. The importance of time is that it contributes to the growth and development of a nation's economy, society, and politics. Furthermore, the process by which politics, society, and economy grow is, in itself, time-dependent. By implication, then, time plays a crucial part in the progress and growth of the economy, politics, environment, and society as a whole. Time, therefore, contributed to the flourishing of socio-cultural, political, environmental, and economic thought. Thus, it can be said that the aforesaid factors proceeds through time. 
In this perspective, it can be concluded that a conducive business environment changes over time, as does the VAT collection, as it is greatly affected by the political, socio-cultural, environmental, and economic downpour or growth. It should be emphasized that economic, political, socio-cultural, and environmental issues speak about the business environment in line with time. This is because the negative relationship can be explained in terms of time based on the economic, political, socio-cultural, and environmental situation of the country. For instance, negative growth in GDP in 2007 was brought about by the worldwide monetary predicament, which greatly affected the economic situation of the ASEAN countries. This global financial crisis affected the business environment because there was an economic failure as well as socio-cultural, environmental, and political instability. In other words, time as a predictor affects the conducive business environment. And as such, a conducive business environment is only possible depending on the time.

The F-ratio of the Philippines (241.114), Indonesia (179.713), and Singapore (297.534) generated a p-value (0.000) less than the level of significance of 0.05 . This relates to the overall significance of the linear trend model. The p-value of the t-statistics of the three (3) selected ASEAN countries showed that the constant is not a significant predictor. However, the time variable transpired to be significant, as evidenced by the p-value (0.000) of the t-statistic of the Philippines (15.572), Indonesia (13.406), and Singapore (17.249).

The beta/regression coefficients of time provide the critical indicator of the formulated linear trend model. The equation specifically relates that, on average, the amount of VAT collections in the Philippines increases at a rate of USD 389.437 million every year. Indonesia and Singapore showed an increase at a rate of USD 2,346.202 million and USD 535.073 million every year, respectively.

\section{Effects of VAT Exemption Policy on Growth Rate in Selected ASEAN Countries}

This research also explored whether the number of VAT exemptions of a country can cause significant differences to its GDP growth rate and amount of VAT collections. The researcher particularly used ANOVA to determine the presence of significant differences. Below is Table 5 showing the result for GDP growth rate and VAT collections of the Philippines, Indonesia, and Singapore.

Table 5. ANOVA results for GDP Growth Rate and VAT Collections Among Philippines, Indonesia, and Singapore

\begin{tabular}{|c|c|c|c|}
\hline & Mean & F-ratio & p-value \\
\hline VAT Colled & & \multirow{4}{*}{27.693} & \multirow{4}{*}{0.000} \\
\hline Philippines & $3,309.90$ & & \\
\hline Indonesia & $19,623.72$ & & \\
\hline Singapore & $4,310.02$ & & \\
\hline GDP Grow & & \multirow{4}{*}{90.332} & \multirow{4}{*}{0.000} \\
\hline Philippines & 1.837 & & \\
\hline Indonesia & 3.694 & & \\
\hline Singapore & 2.075 & & \\
\hline
\end{tabular}

Among the 3 countries, the Philippines has the most number of commodities exempted under the VAT policy. The Philippines has 53 exempted commodities, Indonesia has 37, and Singapore has 7.

When the average VAT collections for each country are explored, results showed that Indonesia has the highest amount of VAT collections, Singapore has the second, and Philippines with the least. The differences in the VAT collections of each country transpired to be statistically significant. This is particularly evident in the p-value (0.000) of the F-ratio (27.693). This, in effect leads to the finding that the VAT collections of each country are statistically different from each other. The same case was observed in the GDP growth rate. As observed, the F-ratio (90.332) has a p-value of 0.000. This relates that there are significant differences observed among the GDP growth rates of the 3 countries. 
Journal of Governance Risk Management Compliance and Sustainability (JGRCS), Vol. 1 (1), 01-17

Effectiveness of the Value Added Tax Exemption Policy on Gross Domestic Product in Selected ASEAN Countries

Towards a Conducive Business Environment Model

Atty. Prackie Jay T. Acaylar, CPA, JD, MPA, PhD-BM, FRILL

The effects of VAT exemption policy on GDP growth rate on selected ASEAN countries can be shown in the regression result shown in Table 6 below.

Table 6. Regression Results: Effects of VAT Exemption Policy on GDP Growth Rate in Selected ASEAN Countries

\begin{tabular}{|l|c|c|c|c|}
\hline \multirow{2}{*}{ Predictors } & \multicolumn{4}{|c|}{ Dependent Variable: GDP Growth Rate } \\
\cline { 2 - 3 } & $\begin{array}{c}\text { Beta } \\
\text { Coefficients }\end{array}$ & $\begin{array}{c}\text { t-statistic } \\
\text { (R-value) }\end{array}$ & $\begin{array}{c}\text { F-ratio } \\
\text { (R-value) }\end{array}$ & R-squared \\
\hline Constant & 4.354 & $\begin{array}{c}21.173 \\
(0.000)\end{array}$ & $\begin{array}{c}89.385 \\
(0.000)\end{array}$ & 0.660 \\
\hline $\begin{array}{l}\text { VAT Exemption } \\
\text { Policy }\end{array}$ & -0.900 & $\begin{array}{c}9.454 \\
(0.000)\end{array}$ & & \\
\hline
\end{tabular}

GDP Growth Rate $\quad=\quad 4.354 \quad-0.900$ VAT Exemption Policy

The researcher used the number of exempted commodities declared by each country in order to measure the effects of VAT exemption policy on the growth rate of GDP. Results of the formulated regression model are as follows:

In terms of R-squared, figures relate that $66 \%$ of the variations in the GDP growth rate are accounted for from the VAT Exemption Policy of the three (3) economies. The F-ratio (89.385) has a pvalue of 0.000 , signifying that the entire regression model is significant. The t-statistics of both the Constant and VAT Exemption Policy have p-values less than the level of significance of 0.05. This, in effect, relates that both the Constant and VAT Exemption policies are significant predictors of GDP Growth Rate.

Given that the beta/regression coefficients are significant, the results of the formulated regression model show that as the number of VAT exempted commodities increases by one unit, the progress rate of the GDP is expected to decrease at a rate of 0.900 units. As results suggest, increasing the number of VAT exempt commodities lowers the GDP growth rate of the considered ASEAN economies.

For better understanding and comparison, the succeeding tables, namely, Tables 7, 8, and 9, will present the individual regression results for the Philippines, Indonesia, and Singapore, respectively.

\section{Regression: Per Country}

Table 7. Regression Results: Effects of VAT Exemption Policy on GDP Growth Rate in the Philippines

\begin{tabular}{|l|c|c|c|c|}
\hline \multirow{2}{*}{ Predictors } & \multicolumn{3}{|c|}{ Dependent Xariable; GDP Growth Rate } \\
\cline { 2 - 3 } & Beta Coefficients & $\begin{array}{c}\text { t-statistic } \\
\text { (p-value) }\end{array}$ & $\begin{array}{c}\text { F-ratio } \\
\text { (p-value) }\end{array}$ & R-squared \\
\hline Constant & 1.478 & $\begin{array}{c}18.254 \\
(0.000)\end{array}$ & 34.661 & \multirow{2}{*}{0.844} \\
\hline VAT Exemption & 0.000 & $\begin{array}{c}5.887 \\
(0.000)\end{array}$ & $(0.000)$ & \\
Policy & & & & \\
\hline
\end{tabular}

GDP Growth Rate $\quad=\quad 1.478+0.000$ VAT Exemption Policy 
Journal of Governance Risk Management Compliance and Sustainability (JGRCS), Vol. 1 (1), 01-17 Effectiveness of the Value Added Tax Exemption Policy on Gross Domestic Product in Selected ASEAN Countries Towards a Conducive Business Environment Model Atty. Prackie Jay T. Acaylar, CPA, JD, MPA, PhD-BM, FRILL

Table 8. Regression Results: Effects of VAT Exemption Policy on GDP Growth Rate in Indonesia

\begin{tabular}{|l|c|c|c|c|}
\hline \multirow{2}{*}{ Predictors } & \multicolumn{4}{|c|}{ Dependent Xariable; GDP Growth Rate } \\
\cline { 2 - 3 } & Beta Coefficients & $\begin{array}{c}\text { t-statistic } \\
\text { (p-value) }\end{array}$ & $\begin{array}{c}\text { F-ratio } \\
\text { (p-value) }\end{array}$ & R-squared \\
\hline Constant & 3.456 & $\begin{array}{c}16.016 \\
(0.000)\end{array}$ & $\begin{array}{c}1.618 \\
(0.224)\end{array}$ & 0.322 \\
\hline $\begin{array}{l}\text { VAT Exemption } \\
\text { Policy }\end{array}$ & 0.000 & $\begin{array}{c}1.272 \\
(0.224)\end{array}$ & \multicolumn{4}{|c|}{} \\
\hline
\end{tabular}

GDP Growth Rate $\quad=\quad 3.456 \quad+0.000$ VAT Exemption Policy

Table 9. Regression Results: Effects of VAT Exemption Policy on GDP Growth Rate in Singapore

\begin{tabular}{|l|c|c|c|c|}
\hline \multirow{2}{*}{ Predictors } & \multicolumn{4}{|c|}{ Dependent Xariable; GDP Growth Rate } \\
\cline { 2 - 4 } & Beta Coefficients & $\begin{array}{c}\text { t-statistic } \\
\text { (p-value) }\end{array}$ & $\begin{array}{c}\text { F-ratio } \\
\text { (p-value) }\end{array}$ & R-squared \\
\hline Constant & 1.310 & $\begin{array}{c}13.455 \\
(0.000)\end{array}$ & $\begin{array}{c}82.759 \\
(0.000)\end{array}$ & 0.925 \\
\hline $\begin{array}{l}\text { VAT Exemption } \\
\text { Policy }\end{array}$ & 0.000 & $\begin{array}{c}9.097 \\
(0.000)\end{array}$ & \\
\hline
\end{tabular}

GDP Growth Rate $\quad=\quad 1.310 \quad+0.000$ VAT Exemption Policy

To measure the effects of the VAT Exemption Policy on the growth rate of GDP in the Philippines, Indonesia, and Singapore, the researcher used the number of exempted commodities declared by each country. Results of the formulated regression model on a per-country basis are as follows:

In terms of R-squared, the Philippines, Indonesia, and Singapore showed figures of $84.4 \%, 32.2 \%$, and $92.5 \%$, respectively. This means that the variations in the GDP growth rate in the Philippines, Indonesia, and Singapore are accounted for from the VAT Exemption Policy. The F-ratio of the Philippines (34.661) and Singapore (82.759) has a p-value of 0.000 (Philippines) and 0.000 (Singapore), signifying that their regression model is significant. The F-ratio of Indonesia, on the other hand, is 1.618 has a p-value of 0.224 .

With the exception of Indonesia, the t-statistics of both the Constant and VAT Exemption Policy have p-values less than the level of significance of 0.05 for the Philippines and Singapore. This, in effect, relates that both the Constant and VAT Exemption policies are significant predictors of GDP Growth Rate for both countries.

\section{Significant Relationship Between VAT Exemption and Growth Rate in ASEAN Region}

$$
\text { GDP Growth Rate }=\quad 4.354 \quad-0.900 \text { VAT Exemption Policy }
$$

Using the regression model result, a negative relationship was observed between VAT exemption policy and GDP Growth Rate among the selected ASEAN economies. It specifically shows that more VATexempt commodities lead to a lower GDP growth rate. Although VAT exemption favors consumers and some sectors of the economy, it appears, more exemptions, fewer earnings/collections, lower GDP growth rate. Thus, tax exemptions can reduce the levels of tax ratios (Ernst and Young, 2015).

Jack (1996) studied VAT collection occurrence in five (5) financial systems in Central and Eastern Europe by assessing income that would have been accumulated when there is no income leak. He maintained that disparities in income performance between countries in the model were possibly to be 
the consequence of VAT exemptions. Hence, irrespective of the problems of circumvention or management efficiency, when a country excludes some goods and transactions from taxation, then its revenue may be lower than another country that did not exclude them. These consequences may indicate that attempts to enhance the revenue collection of VAT could be focused in the direction of diminishing the tax system which exempts goods and services from VAT.

Since the key source for this difference may correlate to the presence of VAT exemptions, regulating and controlling the scope of exemptions in the VAT policy may be imperative because exemptions could ensue in difficult and frequently unfavorable consequences.

On the basis of the foregoing presentation, analysis, and interpretation of results, below is Figure 6 depicting the proposed conducive business environment model:

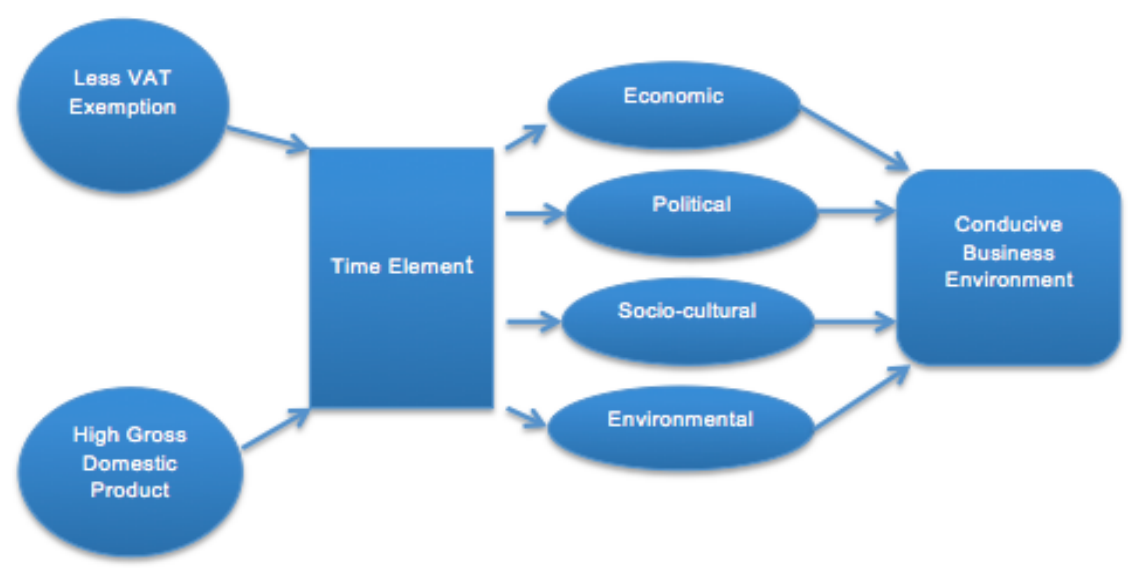

Figure 6. Proposed Conducive Business Environment Model

Figure 6 presents the proposed conducive business environment model as an output of this study based on the results and conclusions. The circle in the upper extreme left shows the VAT exemption policy of the selected ASEAN countries. The study shows that in order for ASEAN countries to increase their VAT collection, these countries must broaden their VAT base by reducing the number of VAT exemptions and limiting these exemptions to raw food and other necessities. Moreover, the conclusion of limiting the VAT to raw food and other necessities is in consonance with the very concept by which VAT was formulated.

The circle in the lower extreme left of the model is the GDP. Based on the study, an increase in GDP would highly contribute to the development of a conducive business environment. It can be noticed that the VAT Exemption policy is a significant predictor of GDP growth rate. Although the VAT collections of the selected ASEAN economies are significantly increasing with the course of time, the results of the formulated regression model also showed that as the number of VAT exempted commodities increases by one unit, the growth rate of the GDP is expected to decrease at a rate of 0.900 units. Thus, increasing the number of VAT-exempt commodities lowers the GDP growth rate of the considered ASEAN economies.

In other words, a negative relationship was observed between VAT exemption policy and GDP growth rate among the selected ASEAN economies, and more VAT exempt commodities lead to lower GDP growth rate.

The box in the middle left shows the Time Element of this study. The importance of time is a tacit assumption in many accounts of financial and fiscal growth. In a time-dependent setting, as in this study, the passage of time implies the improvement and growth of politics, environment, and economy. Thus, 
the passage of time implies growth and development to achieve the conducive business environment model.

And since growth and development occur across time, it is necessary to contemplate the impact of time in VAT collection and on economic efficiency. Thus, the four (4) ovals in the middle right of the model show the four (4) factors that were greatly affected by the Time Element, namely, Economic, Political, Socio-Cultural, and Environmental. These four (4) factors speak about the business environment in line with time. Thus, the negative relationship can be explained in terms of time based on the economic, political, socio-cultural, and environmental situation of the country. And as a predictor, time greatly affects the conducive business environment.

\section{CONCLUSION \& FURTHER RESEARCH}

\section{Future Directions and Implication}

The VAT collections of the selected ASEAN economies are significantly increasing over the course of time. The Philippines, Indonesia, and Singapore showed significant differences in the degree of VAT collections and growth rate. The VAT Exemption Policy can significantly decrease the GDP growth rate of an economy. Prudence dictates that one way to increase the VAT collection is to expand the VAT base by limiting exemptions to raw food and other necessities. Hence, low VAT collection may be attributable to numerous VAT exemptions because VAT-exempt transactions lean towards disrupting the VAT series, which gives rise to high costs and prices and income losses to the Government.

Based on the findings and conclusion of the study, the Government should take into consideration the removal of VAT exemption on Cooperatives. It is noted that exempting cooperatives from the VAT does not protect its buyers because cooperatives will be selling their goods at higher prices to recover the input VAT that they paid when they bought their supplies from a VAT-registered entity. On the other hand, subjecting them to the VAT would allow them to credit the VAT they paid on their inputs against their output VAT. Likewise, the proposed removal of exemption on cooperatives will minimize leakages, especially those cooperatives who are dealing with both members and non-members (Jurado, 2017). In other countries, the Paraguay Ministry of Finance extended VAT to cooperatives as part of their economic and structural reforms to broaden the VAT base and to increase tax collection starting November 1, 2016 (World Bank, 2017). Prior to the VAT imposition, cooperatives were already paying VAT on products and services offered to third parties, but not to those provided to their members (International Co-operative Alliance, 2017). Likewise, in USA, cooperatives typically shell out all the special levies on commercial dealings, including real and property taxes, sales tax (VAT-like tax), employment taxes, gasoline, and diesel fuel taxes, license fees, motor vehicle registration fees, and excise taxes on the telephone, power, and other utility services (USDA, 2017). From the legal perspective, the status quo will encourage other companies to reorganize as cooperatives. With the removal of VAT exemption of the cooperative, companies will be focusing on the business operation instead of creating an identity of a cooperative.

Moreover, the Government should also consider the removal of the VAT exemption on Real Property developed for low-cost and socialized housing. Under the existing law, a real property developed for low cost and socialized housing is exempt from VAT. The removal of this exemption would discontinue the habit of big real estate businesses and condominium developers of splitting their properties into smaller units or parts, or take advantage of transfer pricing schemes and systems so that their properties will fall below the VAT threshold, and, thus, circumventing VAT legal responsibility. From a social viewpoint, Government assistance to focus recipients of socialized and low-cost housing seems to be 
Journal of Governance Risk Management Compliance and Sustainability (JGRCS), Vol. 1 (1), 01-17

Effectiveness of the Value Added Tax Exemption Policy on Gross Domestic Product in Selected ASEAN Countries

Towards a Conducive Business Environment Model

Atty. Prackie Jay T. Acaylar, CPA, JD, MPA, PhD-BM, FRILL

reasonable and justified. However, the lingering query that may be posed: what is the more fitting form of Government assistance in this respect - VAT exemption or direct funding?

Furthermore, future research may focus on the appropriate VAT threshold amount in the Philippines, and other ASEAN countries since the setting of threshold may also be considered as setting VAT exemption.

\section{ACKNOWLEDGMENT}

While this research was mainly developed as an individual endeavor for academic purposes, it was, however, made possible through the collaborative assistance of my friends and colleagues in the academe.

Moreover, I could not have written this research without the ardent and fervent encouragement of my family (Julie, Paolo Juan, and Lucho Alfonso), who supported me with love, affection, and understanding. I am grateful to my students for persuading me to finish this research and pushing me to complete it on a timely basis. Further, I am grateful to my parents for their unwavering support.

And, finally, I thank God Almighty, for the strength and "enlightenment" in completing this research. Ad Majorem Dei Gloriam.

\section{REFERENCES}

Aizenman, J., \& Jinjarak, Y., Kim, J. and Park D., “Tax Revenue Trends in Asia and Latin America: A Comparative Analysis", NBER, Working Paper No. 21755, 2015.

Basri, M. and Rahardja, S., "Mild Crisis, Half Hearted Fiscal Stimulus: Indonesia During the GFC", in Ito, T. and F. Parulian (eds.), "Assessment on the Impact of Stimulus, Fiscal Transparency and Fiscal Risk", ERIA Research Project Report 2010-01, pp.169-211, ERIA, www.eria.org/publications/ research_projectreports/images/pdf/y2010/no1/ch5Basri_andRahardjaIndonesia.pdf, 2011.

Bureau of Internal Revenue (BIR) Annual Report 2008.

Chetty, V. and Pradhan, B., "Harrod-Domar Formula for Two Sector Growth Models," Institute of Economic Growth, Boston University, 2015.

Deloitte, "Risk, uncertainty and opportunity in a changing tax landscape", Deloitte Touche Tohmatsu Ltd., 2014.

Domar, E., "Capital expansion, rate of growth, and employment," Econometrica, 14(2):pp. 147, 1946.

Ernst and Young, "Indirect taxes in 2015", EYG no. DL1195, www.ey.com/Publication/vwLUAssets/ey-indirect-tax-developments-in-2015/\%24FILE/ey-indirecttax-developments-in-2015.pdf, 2015.

Harrod, R., "An essay in dynamic theory," The Economic Journal, 49 (193): pp. 14-33, 1939.

Henegadara, G., "Rostow's Stages of Economic Growth,” University of Kelaniya, 2016.

IBFD, "International Bureau of Fiscal Documentation (website)", https://www.ibfd.org/, 2017.

IMF, "Indonesia, selected issues", IMF Country Report No. 17/48, International Monetary Fund, Washington, DC, https://www.imf.org/ /media/Files/Publications/CR/2017/cr1748.ashx, 2017.

Indonesia Focus, "Achieiving Fiscal Sustainability Key To Fostering Higher Economic Growth", UOB

Global Economics \& Markets Research, Quarterly Global Outlook 2Q 2018.

International Co-operative Alliance, "Paraguay will apply VAT tax on services co-operatives provide

to their members", https://ica.coop/en/media/news/paraguay-will-apply-vat-tax-services-cooperatives- provide-their-members, viewed January 27, 2017. 
International Monetary Fund, "Philippines: 2004 Article IV Consultation and Post-Program Monitoring Discussions - Staff Report; Staff Statement; Statement by the Executive Director for the Philippines; and Public Information Notice on the Executive Board Discussion", IMF Country Report No. 05/105, 2005.

Jack, W., "The efficiency of VAT implementation: a comparative study of Central and Eastern European countries in transition", 1996.

Jurado, F., "Proposed Reforms on Value Added Tax", NTRC Tax Research Journal, Vol. XXIX.3, 2017.

Manasan, R., "Assessment of the 2017 Tax Reform for Acceleration and Inclusion," Philippine Institute for Development Studies, 2017.

Obias, Jr., "Estimates of the Value Added Tax Gap: 2009”, NTRC Tax Research Journal, Vol. XXII.5, 2010.

Parr, J., "On the Regional Dimensons of Rostow's Theory of Growth," The Applied Regional Science Conference, Blackwell Publishers Ltd., 2001.

The World Bank, "Paraguay Overview", http://www.worldbank.org/en/country/ Paraguay/overview, and The International Monetary Fund (IMF), "Paraguay: 2016 Article IV Consultation - Press Release and Staff Report", 2017.

Thirlwall, A., "The Nature of Economic Growth: An Alternative Framework for Understanding the Performance of Nations," E. Elgar, 2002.

UNESCAP, "Economic and Social Survey of Asia and the Pacific 2014", Regional Connectivity for Shared Prosperity, United Nations, https://www.unescap.org/sites/default/files/Economic\%20and \%20Social\%20Survey\%20of\%20Asia\%20and\%20the\%20Pacific\%202014.pdf, 2014.

United States Department of Agriculture (USDA), "Understanding Cooperatives: Income Tax Treatment of Cooperatives", Cooperative Information Report 45, Section 8, http://www.uwcc.wisc.edu/pdf/CIR45-8.pdf, viewed January 27, 2017.

World Bank, "East Asia Pacific Economic Update, October 2015: Staying the Course", Washington, D.C.: World Bank, 2015.

World Bank, "Community Driven Development and Social Capital: Designing a Baseline Survey in the Philippines”, World Bank Report No. 32405-PH, May 2005. 